\title{
Genetic variability in Setchelliogaster tenuipes (Setch.) Pouzar based on DNA barcoding ITS
}

\author{
Sulzbacher MA ${ }^{1 *}$, Bevilacqua $\mathrm{CB}^{1}$, Baldoni $\mathrm{DB}^{1}$, Jacques $\mathrm{RJS}^{1}$ and Antoniolli \\ $\mathbf{Z I}^{1}$
}

${ }^{1}$ Universidade Federal de Santa Maria, Departamento de Solos, CCR Campus Universitário, 971050-900, Santa Maria, Rio Grande do Sul, Brazil

Sulzbacher MA, Bevilacqua CB, Baldoni DB, Jacques RJS, Antoniolli ZI 2017 - Genetic variability in Setchelliogaster tenuipes (Setch.) Pouzar based on DNA barcoding ITS. Mycosphere 8(7), 899-907, Doi 10.5943/mycosphere/8/7/6

\begin{abstract}
Setchelliogaster tenuipes is ectomycorrhizal species with Eucalyptus spp. and currently occurring throughout the world, introduced from Australasia. In South America, it is known from Argentina, Brazil, Uruguay and Chile. Some of the main features of S. tenuipes are the reddish brown basidiomes, presence of stipe, shape of cystidia and peridium structures. The aim of the study is to report the genetic diversity of Setchelliogaster tenuipes (Setch.) Pouzar in Brazil, as well as, in the world distribution. It was presented morphological and phylogenetic notes of this species sampled in Brazil.
\end{abstract}

Key words - ectomycorrhizal fungi - Eucalyptus plantation - nrDNA - sequestrate fungi

\section{Introduction}

Sequestrate form, i.e., fungi with a closed basidiome, occurs in different lineages within the Agaricomycetes. Several studies have shown that sequestrate sporocarps have arisen independent in agaricoid, gasteroid and/or secotioid forms (Peintner et al. 2001, Moncalvo et al. 2002, Hibbett 2007, Tedersoo et al. 2010) as an aid for successful fruiting of basidiomes in different habitats, such as deserts (arid climates) and montane, as well for adaptation to animal dispersal (Castellano et al. 2004, Wilson et al. 2011). Some of sequestrate fungi have secotioid basidiomes. Secotioid fungi are known to the phylum Basidiomycota and comprise fungi where the margin of the pileus does not break free from the stipe (the hymenophore remaining enclosed) lamellae are convoluted and anastomosed, and basidiospores are not ballistosporic (Thiers 1984, Kirk et al. 2008).

The secotioid genus Setchelliogaster was established by Pouzar (1958), and frequently ectomycorrhizal with Eucalyptus (Lago et al. 2001). Up until now only one species was reported from the South of Brazil (S. tenuipes) by Giachini et al. (2000) and Cortez et al. (2008). The systematic position of Setchelliogaster is controversial (Martín \& Moreno 2001, Cortez et al. 2008). Based on the ITS data, is clearly evidenced that Setchelliogaster is a member of /descolea lineage (Peintner et al. 2001, Tedersoo et al. 2010).

The aim of the study is to report the genetic diversity of Setchelliogaster tenuipes from Brazil, as well as, in the world distribution. This report will provide a continuation of previous studies on hypogeous truffle-like fungi of Brazil (Sulzbacher et al. 2010, Cortez et al. 2011, Sulzbacher et al. 2015, 2016). 


\section{Materials \& Methods}

\section{Morphological studies}

Specimens were collected in Eucalyptus plantations in the Rio Grande do Sul state. Macroand microscopic features were described from fresh and dried collections in accordance to Miller \& Miller (1988). Taxonomically relevant microscopic characteristics were photographed with the aid of optical microscopes (Eclipse-Ni Nikon), and microscopy digital camera (DS-Ri1 Nikon). Line drawings of the microstructures were made with the aid of a drawing tube attached to the microscope (BX41 Olympus), at 100x magnification. Color codes followed Kornerup and Wanscher (1978). Prior to storage, basidiomes were dried in forced air with temperature not exceeding $40^{\circ} \mathrm{C}$. Basidiospore mesurements were based on 30 spores mounted in $5 \% \mathrm{KOH}$ and stained with Congo red following methodology proposed by Tulloss et al. (1992). Abbreviations include $\mathrm{L}(\mathrm{W})$ = average basidiospore length (width), $\mathrm{Q}=$ the length: width ratio range as determined from all measured basidiospores, and $\mathrm{Qm}=$ the $\mathrm{Q}$ value averaged from all basidiospores measured, and $n=$ the number of spores measured. Spore surface details were additionally analyzed under scanning electron microscope (SEM) following methodology in Sulzbacher et al. (2013). The samples studied were deposited in the fungal collection from the Herbaria UFRN and SMDB. Herbaria acronyms follow Thiers (2015).

\section{Molecular analysis}

The DNA isolation was carried out from a fraction of fresh basidiome stored in CTAB (Gardes \& Bruns 1993) at $-20^{\circ}$. DNA was extracted with the DNeasy® Plant Mini Kit (Qiagen, São Paulo, Brazil). The ITS1-5.8S-ITS2 fragment of nrDNA region was amplified with primers ITS1 and ITS4 (White et al. 1990). The amplification reaction of the rDNA fragments was performed according to Baldoni et al. (2012), followed by electrophoresis at $1.5 \%$ agarose gel at $1 \mathrm{X}$ TBE buffer. The DNA samples were stained with BlueGreen Loading Dye I ® (LGC Biotechnology, Cotia, Brazil) and observed under UV light. The PCR products were purified with Gen Elute PCR Clean-up Kit@ (Sigma, St. Louis, USA) kit, following the manufacturer's instructions. Sequencing of the samples was performed into the sequencer, ABI PRISM 3100 Genetic Analyzer (Applied Biosystems). Sequences were analyzed with the Staden Package 2.0.0b software (Staden et al. 2003). Consensus sequences were deposited in the GenBank and a comparative search by means of BLASTn was perfomed. For identification of collected specimens, sequences (accession numbers NCBI KX025104 and KX025105) were aligned by BioEdit version 7.2.5 (Hall 1999). The phylogenetic relationship of the specimens was reconstructed based on analyses of the ITS region in MEGA 5.0 software (Tamura et al. 2011), with the analysis of Maximum Likelihood (ML) in a total of 1000 replications. The General Time Reversible nucleotide substitution model with Gamma distributed with Invariante sites and parameters for partial exemption (95\%) was estimated as best substitution model using MEGA 5.0 software (Tamura et al. 2011). Selected closely related sequences for phylogenetic analysis of the genus Setchelliogaster were retrieved from the GenBank database (http://www.ncbi.nlm.nih.gov/genbank/). Sequences of Hebeloma pallidolabiatum (KM390703) and H. aurantioumbrinum (KM390686) were included as outgroup.

The GUIDANCE web server (Sela et al. 2015) is a powerful and user-friendly tool to carried out detections at unreliable regions as for example from ITS region. This software identify uncertainty in the process of indel formation, uncertainty in the assumed guide tree and co-optimal solutions in the pairwise alignments, used as building blocks in progressive alignment algorithms. Accordingly, this algorithm is able to overall alignment confidence scores were retrieved. In addition, the alignment program carried out was Clustal $\mathrm{W}$ and Bioedit, these were the root to upload Guidance and it was used with default parameters.

\section{Results}




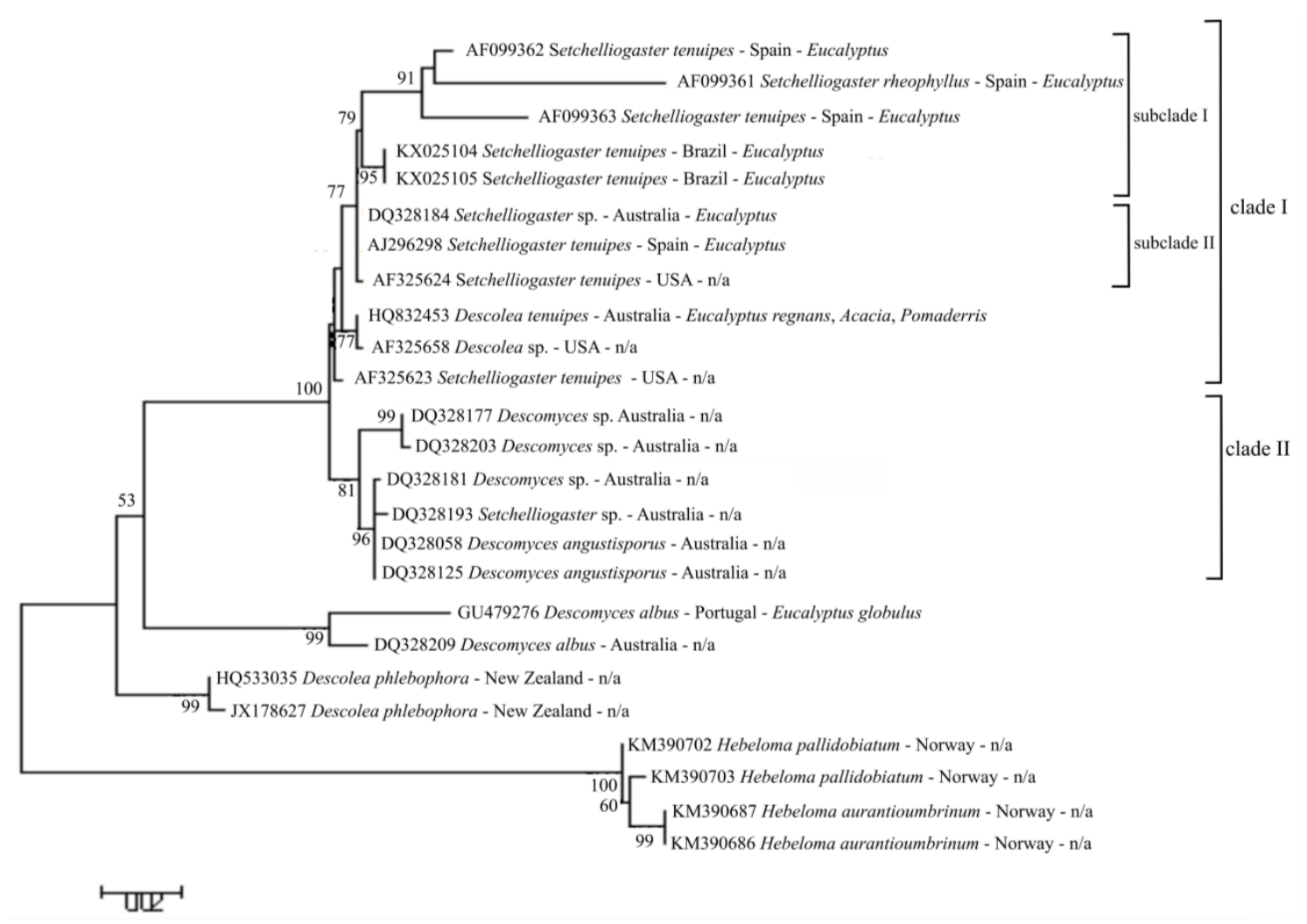

Fig. 1 Phylogram of the Setchelliogaster tenuipes inferred from ITS1-5.8S-ITS2 sequences, using maximum likelihood analysis. Bootstrap values which are greater than $50 \%$ are shown at the branches. The tree is rooted to Hebeloma pallidobiatum and H. aurantioumbrinum.

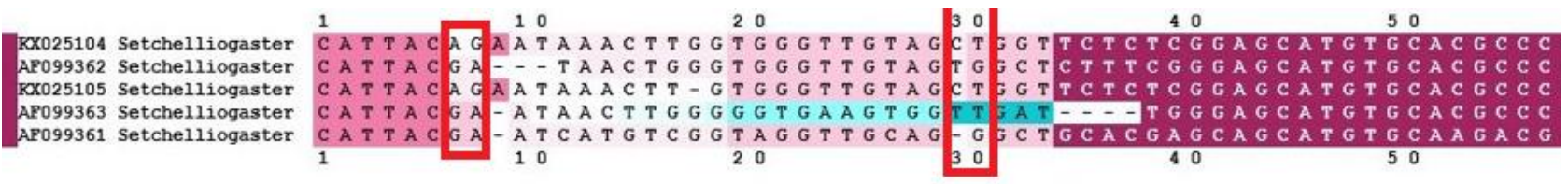

Fig. 2 Selected ITS alignments obtained by GUIDANCE web server for Setchelliogaster sequences clustered at Subclade I.

\section{Molecular analyses}

Two available collections of presumable Setchelliogaster tenuipes (UFRN-fungos 2116 and SMDB 13.103) were successfully retrieved (accession numbers NCBI KX025104 and KX025105) and included in phylogenetic analysis. The best-scoring ITS Maximum Likelihood analyses revealed two separate big clades and two distinguished subclades (Fig. 1). The two Brazilian isolates were well-supported with Setchelliogaster tenuipes sequences from GenBank in the subclade I (Fig. 1), which is confirmed by Guidance analysis, which one showed a difference between AF099363, AF099362 and AF099361 with KX025104 and KX025105 (Fig. 2). At this same figure are showed that KX025104 and KX025105 have some hotspot, each ones are the same at Brazilian access (KX025104 and KX025105) therefore distinguishing at Spain access at subclade I (highlighted in red boxes at Fig. 2). Inversion base can clearly identify the similarity with Brazilian access and Australian (DQ328184 and KX025104).

There is a sharp and long distance relationship between New Zealand and others access from Genbank. Which suggest the New Zealand access have a different mechanism of evolution. As well as Australian Descomyces, keeping linked Descomyces and New Zealand S. tenuipes, according to evolutionary studies (Tedersoo et al. 2010).

\section{Taxonomy}



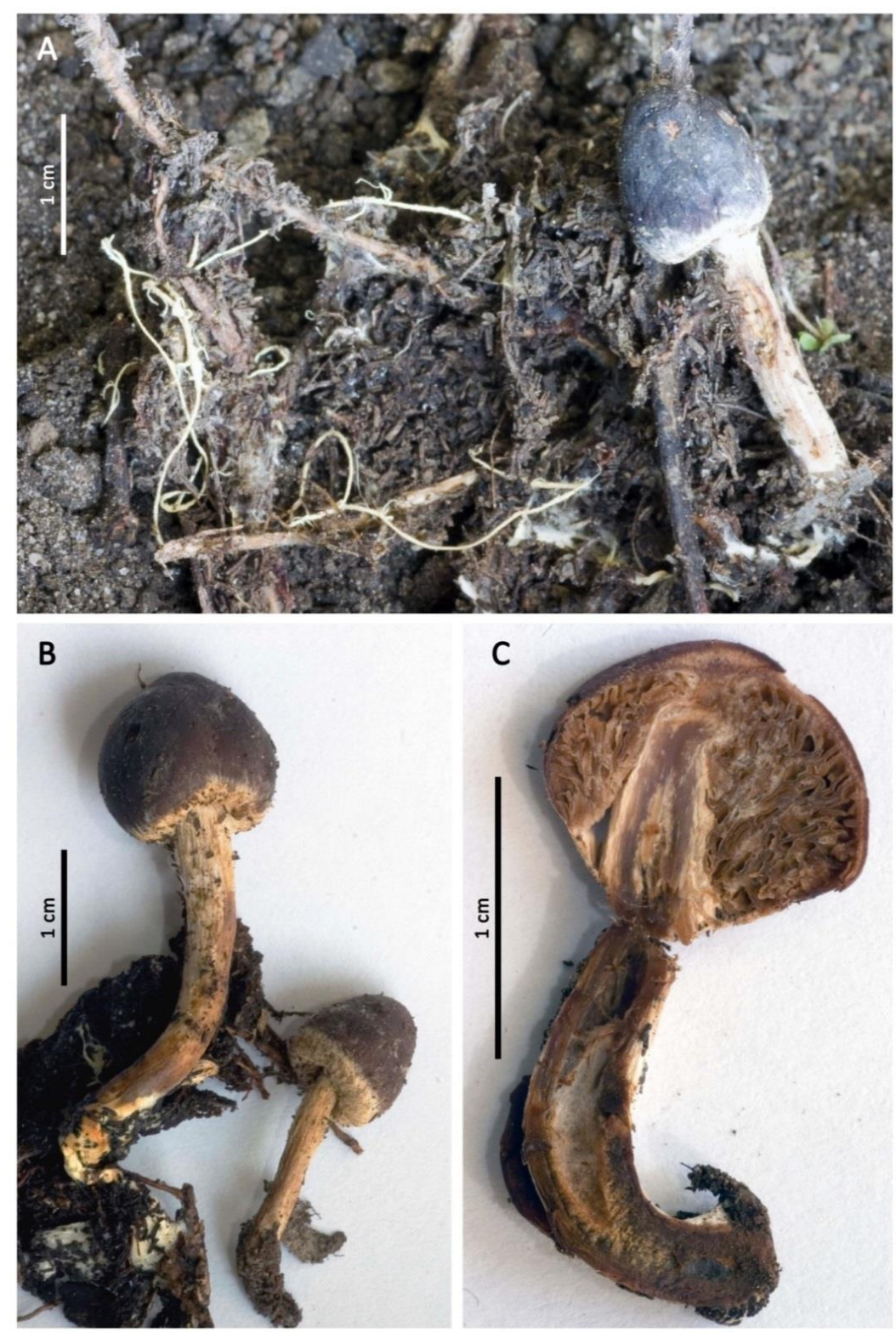

Fig. 3 A-C Setchelliogaster tenuipes. A Fresh mature basidioma attached to yellowish rhizomorphs. B-C Basidioma

Setchelliogaster tenuipes (Setch.) Pouzar, Česká Mykol. 12: 34. 1958.

Figs. 3-6

Hypogeous, in Eucalyptus litter, under Eucalyptus grandis, ectomycorrhizal. Specimens were frequently observed close to the root collar of Eucalyptus grandis. Basidiomes secotioid, stipitate and with a globose and enclosed pileus, 25-39 mm high (Fig. 3). PILEUs 7-13 mm diam., 9-12 mm high, conic to subglobose. Peridium reddish brown (9E8) to dark brown (9F6), margin of the pileus (peridium) concolor to the stipe, olive brown (4D7), velutinouse; 0.5 to $1 \mathrm{~mm}$ thick, surface dry and smooth. Stipe 18-23 × 2-4 mm, sinuous or erect, olive brown (4D7), with a bulbous base slightly developed, attached to soil and roots by whitish (2A1) and grayish yellow (1B6) thin rhizomorphs; surface striate and fibrillate, in some stipe a white surface is present; hollow. Columella continuous with the stipe, crossing the entire extension of the gleba. Gleba light brown (7D7) to pastel red (7A5) near to the stipe, loculate, formed by anastomosed lamellae (Fig. 3C). Basidiospores (11-) 12-16 × 8-10 $\mu \mathrm{m}(\mathbf{L}=13.5 \mu \mathrm{m}, \mathbf{W}=9.1 \mu \mathrm{m}, \mathbf{Q}=(1.2-) 1.3-1.7, \mathbf{Q m}=1.5), \mathrm{n}=30$ (of one basidiomata), ovoid to ellipsoid in both face and side views, rusty under $5 \% \mathrm{KOH}$, with a punctuate and thickened wall ( $<1 \mu \mathrm{m}$ broad), apiculus prominent (Fig. 4C-F). Under SEM, basidiospore surface presents several irregular depressions varying in size and form (Fig. 6A-B). 

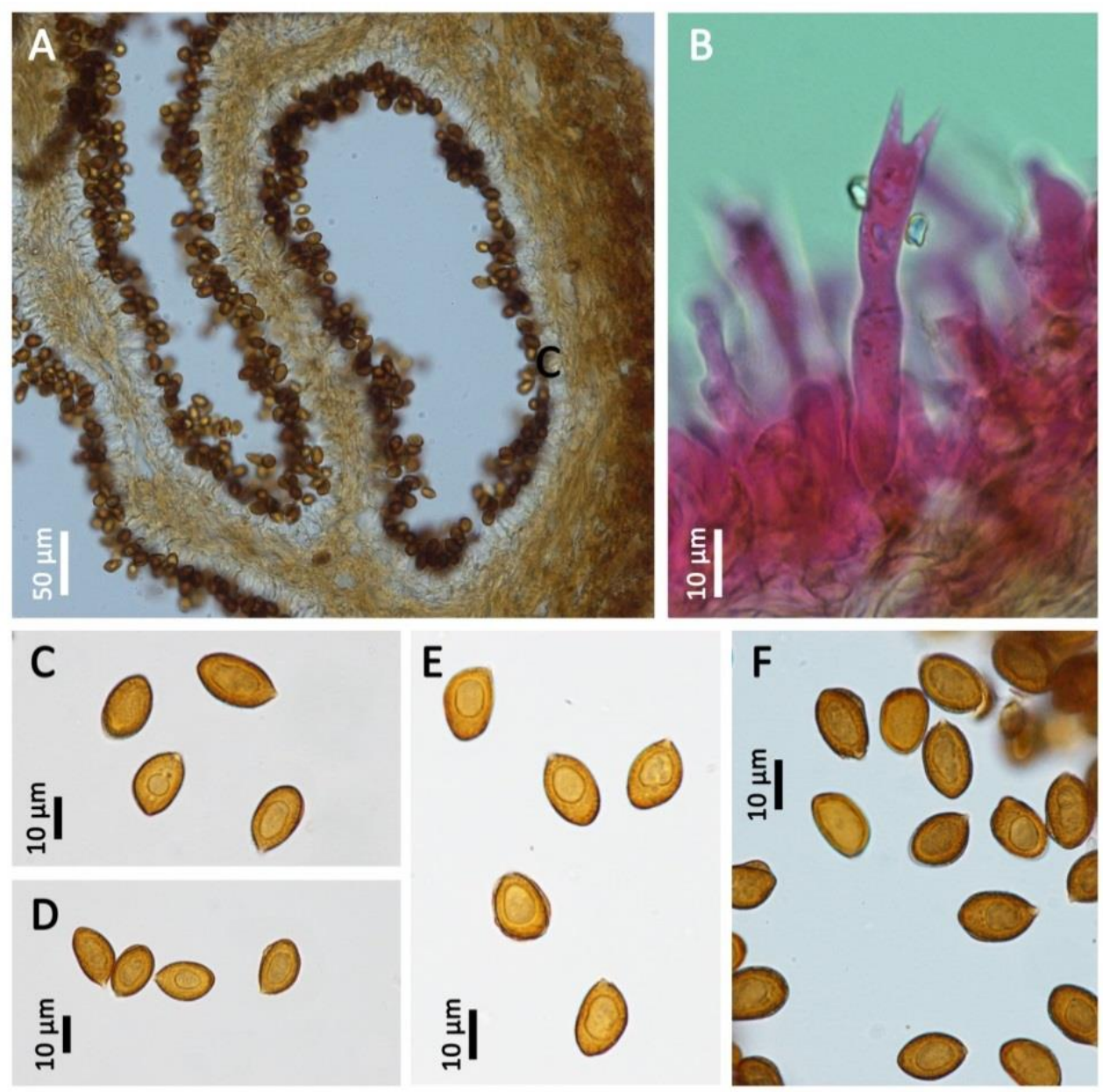

Fig. 4 A-F Setchelliogaster tenuipes. A Hymenophoral trama. B Basidia. C-F Basidiospores

Basidia $28-47 \times 7-8.5 \mu \mathrm{m}$, clavate to cylindric, hyaline and thin walled, mainly producing two basidiospores, sterigmata 3-6 $\mu \mathrm{m}$ long (Fig. 4B, 5A). Cheilocystidia 27.5-36 × 9-15 $\mu \mathrm{m}$, hyaline and thin-walled, lecythiform to lageniform, with a distinct capitate, globose apex 3-4.5 $\mu \mathrm{m}$ diam (Fig. 5 D). Peridium two layered: the external layer formed by pseudoparenchymatic, composed by subglobose hyphae, 8-37.5 $\mu \mathrm{m}$ diam., smooth, with thin- to slightly thickened walls, hyaline to yellowish brown walls, over a filamentous layer of hyaline to yellowish, with or without granular, hyaline or yellowish-brown content, 5-14 $\mu \mathrm{m}$ diam., clamp connections present (Fig. 5B). Hymenophoral trama subparallel, hyphae 4-12 $\mu \mathrm{m}$ diam., with thin walls, hyaline or yellowishbrown pigments in bands, hyphae with elongate-inflated elements 11-15 $\mu \mathrm{m}$ diam., with clamp connections (Fig. 4A). Stiptipellis subparallel, hyphae 1.5-9 $\mu \mathrm{m}$ diam., with thin- to thick-walled (up to $1 \mu \mathrm{m}$ diam.), with clamp connections, hyaline, yellowish or with granulose yellow brown contents, surface with ornamented bands. Caulocistydia was not observed. Rhizomorphs 2-8 $\mu \mathrm{m}$ diam., formed by hyaline hyphae, smooth, or with the surface encrusted with granular, angular crystals 2.5-6.5 $\mu \mathrm{m}$ diam., or in an amorphous mass, crystals rapidly dissolving in concentrated 5\% $\mathrm{KOH}$, thin-walled, clamps very frequently, with irregularly branched, 7-14 $\mu \mathrm{m}$ diam., thinner rhizomorphs undifferentiated, 2-6 $\mu \mathrm{m}$ diam., hyaline (Fig. 5C, 6C-E). Many emanating hyphae in "H" form, thin-walled, and with scarcely ampullately inflated hyphal portions (3-10 $\mu \mathrm{m}$ diam.) (Fig. Fig. 5G-H). Some hyphae with a thickish or thick wall (up to $1.5 \mu \mathrm{m}$ diam.), with clamp connections, brown contents, surface smooth, 2.5-5 $\mu \mathrm{m}$ diam (Fig. 5E). Terminal hyphae rounded to narrowed (Fig. 5F). Chlamydospores were not observed. 

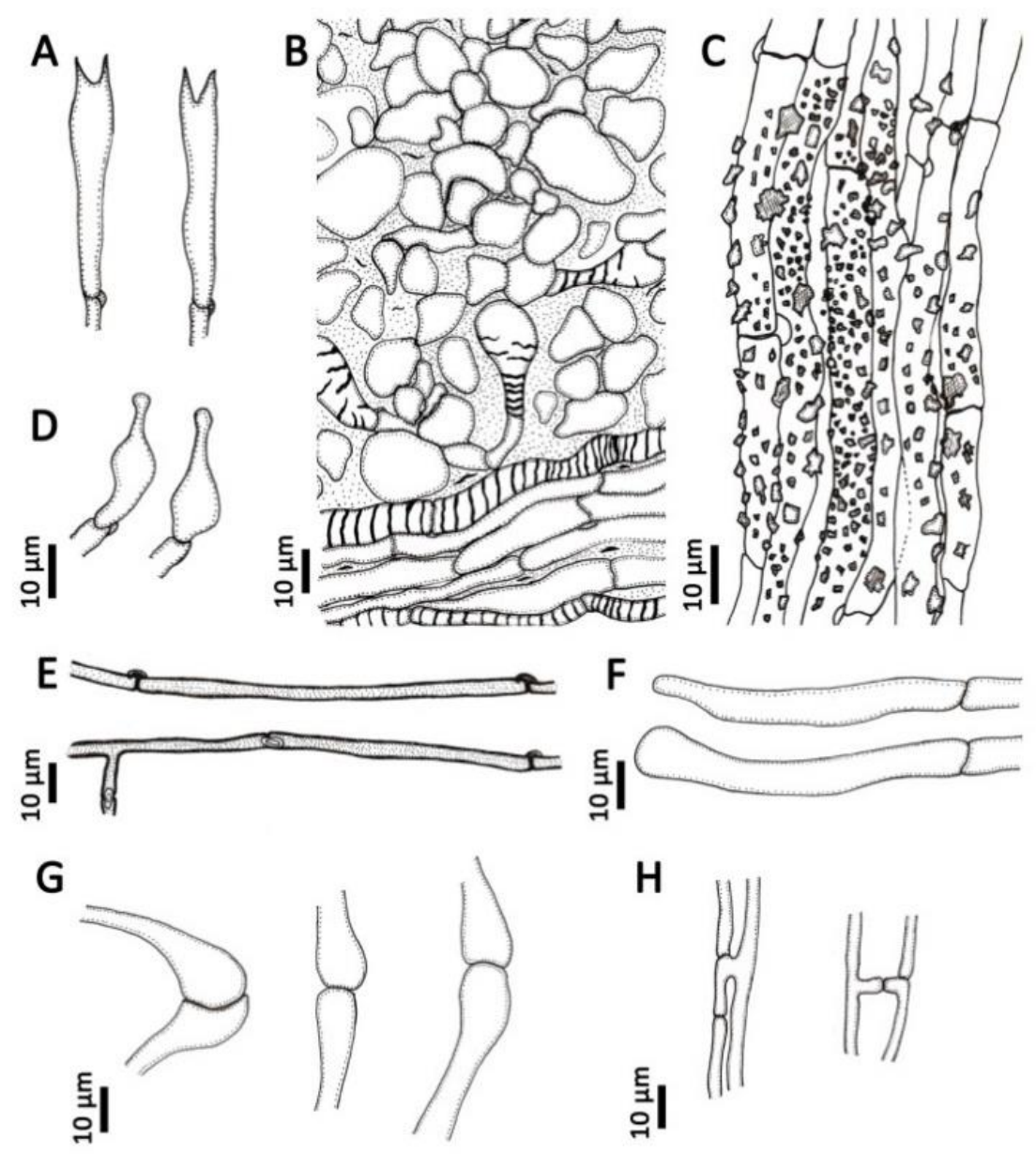

Fig. 5 A-H - Setchelliogaster tenuipes. A Basidia. B Details of the peridiopellis. C Details of the external surface of rhizomorphs with encrusted granular crystals. D Cheilocystidia. E-H Rhizomorphs structures. E Thicker hyphae with simple septa, clamps and brown content. F Terminal hyphae. G Ampullate inflations at the hyphae. $\mathbf{H}$ Emanating hyphae.

Specimens examined - BRAZIL, Rio Grande do Sul, Santa Maria, Boca do Monte District, Estação Experimental de Silvicultura-FEPAGRO, 29³0'27.2”S 5354'49.8”W, 31.VII.2009, leg. M.A. Sulzbacher 198 (SMDB 13.103); ibid., 17. VII.2012, leg. D.F. Montagner (DFM02, SMDB); Barra do Quaraí, 28 55'22.2"S 5606'42.0"W, 24.VIII.2011, leg. A. Silveira \& M.A. Sulzbacher

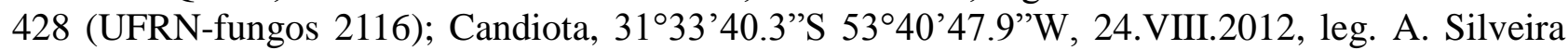

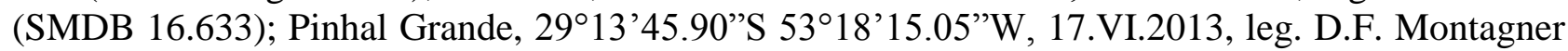
(SMDB 16.635).

\section{Discussion}

Setchelliogaster tenuipes is widespread and ectomycorrhizal with Eucalyptus plantations (Grgurinovic 1997, Lago \& Castro 2004). In South America, it is known from Argentina and Uruguay (Horak 1964, Singer 1969, Wright 1980, Nouhra et al. 2008), Chile (Lazo 1972). In Brazil, the species was only reported from the South (Giachini et al. 2000, Cortez et al. 2008). During our studies, $S$. tenuipes was collected in eucalyptus plantation from several localities of the State of Rio Grande do Sul. The species is common in the South of Brazil, however, only occurring in exotic forests. Setchelliogaster tenuipes is frequently restricted to this host family in South of Brazil, as the same from Australia, Europe, New Zealand, and USA (Lago \& Castro 2004). 

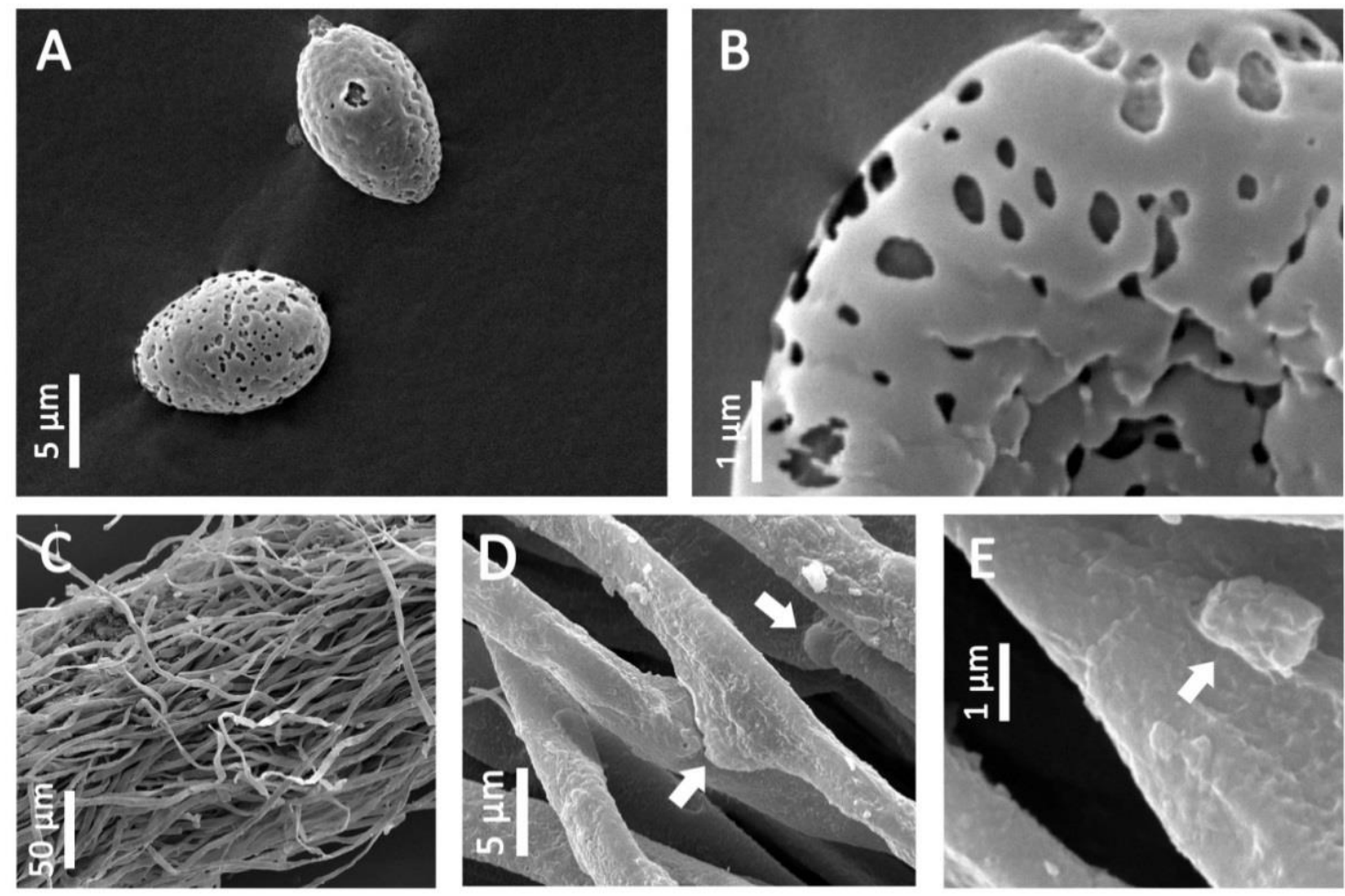

Fig. 6 A-E - Setchelliogaster tenuipes SEM photographs. A-B Basidiospores. C-E details of the rhizomorphs. C Longitudinal view of a rhizomorph. D Rhizomorph surface with details of the clamped hyphae (arrows). E Rhizomorph crystals (arrow).

The taxonomic placement and limits of Setchelliogaster tenuipes within the genus were discussed in Lago et al. (2001) and Cortez et al. (2008). Some of the main features of S. tenuipes are the reddish brown basidiomes, the presence of a well-developed stipe, lecythiform cystidia, peridium layer formed by pseudoparenchymatic elements (Montecchi \& Sarasini 2000, Lago \& Castro 2004). According to Bougher \& Castellano (1993), the genus is ectomycorrhizal with Eucalyptus but also with Myrtaceae. These authors report that Setchelliogaster tenuipes often accompanies Descomyces albus as one of the few compatible ectomycorrhizal fungi occurring in great abundance in Eucalyptus plantations in Australia. This statement has been confirmed in Brazil (Giachini et al. 2000). The rhizomorph structures are described here both macro- and microscopically, as some studies has pointed out (Agerer \& Iosifidou 2004, Agerer 2006, Clémençon et al. 2007, Marino et al. 2008). Clémençon et al. (2007) reported that different developmental and architectural rhizomorph types are distinguished in several groups of fungi (Geastrales, Lycoperdales), and these depend on the presence and distribution of vessel-like hyphae, ampullate swellings at the septa, fibre hyphae, secretory hyphae and backward growing hyphae.

\section{Acknowledgements}

The authors wish to thank Dr. Tine Grebenc (Slovenian Forestry Institute, Slovenia) and an anonymous reviewer with constructive editorial critiques. We thank financial support from CAPES (scholar, proceeding PNPD20132624/42002010027P4-UFSM/Ciência do Solo), FAPERGS and CNPq.

\section{References}

Agerer R. 2006 - Fungal relationships and structural identity of their ectomycorrhizae. Mycological Progress 5: 67-107. 
Agerer R. 2006 - Fungal relationships and structural identity of their ectomycorrhizae. Mycological Progress 5: 67-107.

Agerer R, Iosifidou P. 2004 - Rhizomorph structure of Hymenomycetes: a possibility to test DNA based phylogenetic hypotheses? In: Agerer, R., Piepenbring, M., Blanz, P. (eds.) Frontiers in Basidiomycote Mycology. I.H.W. Verlag, Eching, vol. 2, pp. 249-302.

Baldoni DB, Coelho G, Jacques RJS, Silveira RMB, Grebenc T, Antoniolli ZI. 2012 - Brown rotting fungus closely related to Pseudomerulius curtisii (Boletales) recorded for the first time in South America. Mycosphere 3(5), 533-541.

Bougher NL, Castellano MA. 1993 - Delimitation of Hymenogaster sensu stricto and four new segregated genera. Mycologia 85: 273-293.

Castellano, MA, Trappe JM, Luoma DL. 2004 - Sequestrate Fungi. In: Mueller GM, Bills GF, Foster MS. (eds.) Biodiversity of fungi. Inventory and monitoring methods. Boston, Elsevier Academic Press, vol. 1, pp. 197-213.

Clémençon H, Hosaka K, Taylor AFS. 2007 - Rhizomorph anatomy confirms the taxonomic position of Sclerogaster (Phallomycetidae, Basidiomycota). Mycotaxon 100: 85-95.

Cortez VG, Baseia IG, Guerrero RT, Silveira RMB. 2008 - Two sequestrate cortinarioid fungi from Rio Grande do Sul State, Brazil. Hoehnea 35: 513-518.

Cortez VG, Sulzbacher MA, Baseia IG, Antoniolli ZI, Silveira RMB. 2011 - New records of Hysterangium (Basidiomycota) in Eucalyptus plantations of south Brazil. Rev. Bras. de Biociências 9: 220-223.

Gardes M, Bruns TD. 1993 - ITS primers with enhanced specificity for basidiomycetes application to the identification of mycorrhizae and rusts. Molecular Ecology 2: 113-118.

Giachini AJ, Oliveira VL, Castellano MA, Trappe JM. 2000 - Ectomycorrhizal fungi in Eucalyptus and Pinus plantations in southern Brazil. Mycologia 92: 1166-1177.

Grgurinovic CA. 1997 - Larger fungi of South Australia. The Botanic Gardens of Adelaide and State Herbarium and the Flora and Fauna of South Australia Handbooks Committee, Adelaide, Australia.

Hall TA 1999 - BioEdit: a user-friendly biological sequence alignment editor and analysis program for Windows 95/98/NT. Nucleic Acids Symposium Series 41: 95-98.

Hibbett DS. 2007 - After the gold rush, or before the flood? Evolutionary morphology of mushroom-forming fungi (Agaricomycetes) in the early $21^{\text {st }}$ century. Mycological Research 111: 1001-1018.

Horak E. 1964 - Fungi austoamericani. VII. Hypogaea gen. nov. - aus dem Nothofagus-Wald der patagonischen Anden. Sydowia 17: 297-301.

Kirk PM, Cannon PF, Minter DW, Stalpers JA. 2008 - Dictionary of the Fungi. $10^{\text {th }}$ edition CABI International, Wallingford, UK.

Kornerup A, Wanscher JE. 1978 - Methuen Handbook of Colour, $3^{\text {th }}$ edn., London Methuen.

Lago M, Castro ML. 2004 - Macrobasidiomicetos asociados a Eucalyptus en la Península Ibérica. Fungi Non Delineati 27: 1-84.

Lago M, Bougher NL, Castro ML. 2001 - Morphological variability and implication for definition of taxa in the Descolea-Setchelliogaster-Descomyces complex. Mycotaxon 78: 37-57.

Lazo W. 1972 - Fungi from Chile I. Some gasteromycetes and Agaricales. Mycologia 64: 786798.

Marino DE, Scattolin L, Bodensteiner P, Agerer R. 2008 - Sistotrema is a genus with ectomycorrhizal species - confirmation of what sequence studies already suggested. Mycological Progress 7: 169-176.

Martín MP, Moreno G. 2001 - Molecular data confirm Setchelliogaster tenuipes and S. rheophyllus as Cortinariales. Mycotaxon 78: 257-263.

Miller JrOK, Miller HH. 1988 - Gasteromycetes: morphology and developmental features. Mad River, Eureka, CA. 
Moncalvo JM, Vilgalys R, Redhead SA, Johnson JE, James TY, Aime MC, Hofstetter V, Verduin SJW, Larsson E, Baroni TJ, Thorn RG, Jacobsson S, Clémençon H, Miller Jr OK. 2002 One hundred and seventeen clades of euagarics. Molecular Phylogenetics and Evolution 23: 357-400.

Montecchi A, Sarasini M. 2000 - Funghi ipogei d'Europa. Fondazione Centro Studi Micologici dell Associazione Micologica Bresadola, Trento.

Nouhra E, Dominguez LS, Daniele GG, Longo S, Trappe JM, Claridge AW. 2008 - Ocurrence of ectomycorrhizal, hypogeous fungi in plantations of exotic tree species in central Argentina. Mycologia 100: 752-759.

Peintner U, Bougher NL, Castellano MA, Moncalvo JM, Moser MM, Trappe JM, Vilgalys R. 2001 - Multiple origins of sequestrate fungi related to Cortinarius (Cortinariaceae). American Journal of Botany 88: 2168-2179.

Pouzar Z. 1958 - Nova genera macromycetum II. Ceská Mykologie 12: 31-36.

Singer R. 1969 - Mycoflora Australis. Beihefte zur Nova Hedwigia 29: 1-405.

Staden R, Judge DP, Bonfield JK. 2003 - Analysing sequences using the Staden package and EMBOSS. Introduction to Bioinformatics. A Theoretical and Practical Approach. Eds. Stephen A. Krawetz and David D. Womble. Human Press Inc., Totawa, NJ 07512. pp. 393410.

Sela I, Ashkenazy H, Katoh K, Pupko T. 2015 - GUIDANCE2: accurate detection of unreliable alignment regions accounting for the uncertainty of multiple parameters. Nucleic Acids Research 43 (Web Server issue): W7-W14.

Sulzbacher MA, Cortez VG, Coelho G, Jacques RJS, Antoniolli ZI. 2010 - Chondrogaster pachysporus in a Eucalyptus plantations of southern Brazil. Mycotaxon 113: 377-384.

Sulzbacher MA, Cortez VG, Baseia IG. 2013 - Rediscovery of Pseudocolus garciae in southern Brazil. Mycotaxon 123: 113-119.

Sulzbacher MA, Grebenc T, Köhler A, Antoniolli ZI, Giachini AJ, Baseia IG. 2015 - Notes on mycophagy of Descomyces albus (Basidiomycota) in southern Brazil. Mycosphere 6: 620 629.

Sulzbacher MA, Grebenc T, García MA, Silva BD, Silveira A, Antoniolli ZI, Marinho P, Münzenberger B, Telleria MT, Baseia IG, Martín MP. 2016 - Molecular and morphological analyses confirm Rhizopogon verii as a widely distributed ectomycorrhizal false truffle in Europe, and its presence in South America. Mycorrhiza 26: 377-388.

Tamura K, et al. 2011 - MEGA5: Molecular Evolutionary Genetics Analysis using Maximum Likelihood, Evolutionary Distance, and Maximum Parsimony Methods. Molecular Biology and Evolution 28: 2731-2739.

Tedersoo L, May TW, Smith ME. 2010 - Ectomycorrhizal lifestyle in fungi: global diversity, distribution, and evolution of phylogenetic lineages. Mycorrhiza 20: 217-263.

Thiers HD. 1984 - The secotioid syndrome. Mycologia 76: 1-8.

Thiers, B. 2015 - Index Herbariorum: A global directory of public herbaria and associated staff. http://sweetgum.nybg.org/ih/

Tulloss RE, Ovrebo CL, Halling RE. 1992 - Studies on Amanita (Amanitaceae) from Andean Colombia. Mem. New York Bot. Gard. 66: 1-46.

White TJ, Bruns T, Lee S, Taylor J. 1990 - Amplification and direct sequencing of fungal ribosomal RNA genes for phylogenetics. In: Innis, Innis MA; Gelfand DH. (Eds.) PCR protocols. A guide to methods and applications. Academic Press, San Diego. p. 315- 322.

Wilson AW, Binder M, Hibbett D. 2011 - Effects of gasteroid fruiting body morphology on diversification rates in three different clades of fungi estimated using binary state speciation and extinction analysis. Evolution 65: 1305-1322.

Wright JE. 1980 - El género Setchelliogaster en Buenos Aires (Secotiaceae, Gasteromycetes). Boletín de la Sociedad Argentina de Botánica 19: 237-241. 